\title{
Linear pentacobalt complexes: synthesis, structures, and physical properties of neutral and one-electron oxidation compounds
}

\author{
Chen-Yu Yeh, ${ }^{a}$ Chung-Hsien Chou, ${ }^{a}$ Kun-Chih Pan, ${ }^{a}$ Chih-Chieh Wang, ${ }^{a}$ Gene-Hsiang Lee, ${ }^{a}$ \\ Y. Oliver Su ${ }^{a}$ and Shie-Ming Peng *a,b \\ a Department of Chemistry, National Taiwan University, Taipei, Taiwan, ROC. \\ E-mail: smpeng@mail.ch.ntu.edu.tw \\ ${ }^{b}$ Institute of Chemistry, Academia Sinica, Taipei, Taiwan, ROC
}

Received 17th December 2001, Accepted 2nd May 2002

First published as an Advance Article on the web 28th May 2002

\begin{abstract}
A series of linear pentanuclear cobalt complexes, including both neutral and one-electron oxidized forms, have been synthesized. The one-electron oxidation products were prepared either by reaction with silver salts or by bulk electrolysis. In all of these complexes, the pentacobalt chain adopts a symmetrical arrangement and is helically wrapped by four tpda [the dianion of $N, N^{\prime}$-bis( $\alpha$-pyridyl)-2,6-diaminopyridine] ligands. Two sets of Co-Co bond distances are observed, in which the average internal (inner) bond is about $0.06 \AA$ shorter than the external (outer) one. After one-electron oxidation, the average $\mathrm{Co}-\mathrm{Co}$ and $\mathrm{Co}-\mathrm{N}$ bond distances are not significantly different from those of the neutral analogues, whereas the $\mathrm{Co}-\mathrm{X}(\mathrm{X}=$ axial ligand $)$ bond lengths exhibit a slight decrease in length. All of these complexes show two reversible redox couples at about +0.35 and $+0.85 \mathrm{~V}$ ( $v \mathrm{~s}$. Ag/AgCl). The first oxidation is a metal-centered reaction and the product has been structurally characterized. The second oxidation product is stable on the time scale of spectroelectrochemistry, but undergoes reduction to form the corresponding one-electron oxidation product under the crystallization conditions. The NMR results are consistent with the paramagnetism of both the neutral and oxidized complexes. The magnetic measurements indicate that the neutral and one-electron oxidized molecules have spin states of $S=1 / 2$ and 1 , respectively.
\end{abstract}

\section{Introduction}

The metal-metal interactions in dinuclear complexes have been intensively studied and are well understood. ${ }^{1-4}$ Multinuclear compounds with oligo- $\alpha$-pyridylamine as the supporting ligand have received increasing attention, due to their versatile chemical and physical properties and their potential application as molecular metal wires, since the first reports of trinuclear copper and nickel complexes bridged by the di- $\alpha$-pyridylamido ligand in $1990-1991{ }^{5,6}$ In the past decade, a number of tri- ${ }^{7-10}$ tetra, ${ }^{11}$ penta-,${ }^{12-15}$ hepta-,${ }^{11,16}$ and nonanuclear ${ }^{17}$ metal string complexes have been successfully synthesized and structurally characterized.

In 1994, we reported the first asymmetrical structure of a tricobalt complex $\left[\mathrm{Co}_{3}(\mathrm{dpa})_{4} \mathrm{Cl}_{2}\right](\mathrm{dpa}=$ the dianion of dipyridylamine), in which the central cobalt ion forms a metal-metal bond with one of the two terminal cobalt ions and leaves the other terminal cobalt ion isolated. ${ }^{7}$ Three years later, the symmetrical structure of this complex was discovered by Cotton and co-workers. ${ }^{10}$ Further work by the same group confirmed that both symmetrical and asymmetrical structures can exist. In this class of linear metal string complexes, both symmetrical and asymmetrical structures were only found for molecules with a trichromium, ${ }^{9}$ tricobalt, ${ }^{10}$ or pentachromium core ${ }^{14,15}$ In order to investigate whether compounds other than above multinuclear metal complexes can adopt both symmetrical and asymmetrical structures, we decided to synthesize the pentacobalt complexes. In our previous brief communication, ${ }^{12}$ we described the synthesis, crystal structure, and magnetic properties of $\left[\mathrm{Co}_{5}(\mathrm{tpda})_{4}(\mathrm{NCS})_{2}\right]$, where tpda is the dianion of $N, N^{\prime}$-bis $(\alpha$-pyridyl)-2,6-diaminopyridine (tripyridyldiamine, abbreviated to tpdaH $\mathrm{H}_{2}$ ). Unlike the case of $\left[\mathrm{Co}_{3}(\mathrm{dpa})_{4} \mathrm{Cl}_{2}\right]$, wherein both asymmetrical and symmetrical structures can exist, the five cobalt atoms in $\left[\mathrm{Co}_{5}(\mathrm{tpda})_{4}(\mathrm{NCS})_{2}\right]$ can only exist in a symmetrical arrangement. Theoretical calculations show that the bond order between adjacent cobalt atoms is 0.5 with $\sigma$ character (Fig. 1). ${ }^{13}$ It is desirable to study how the nature of the

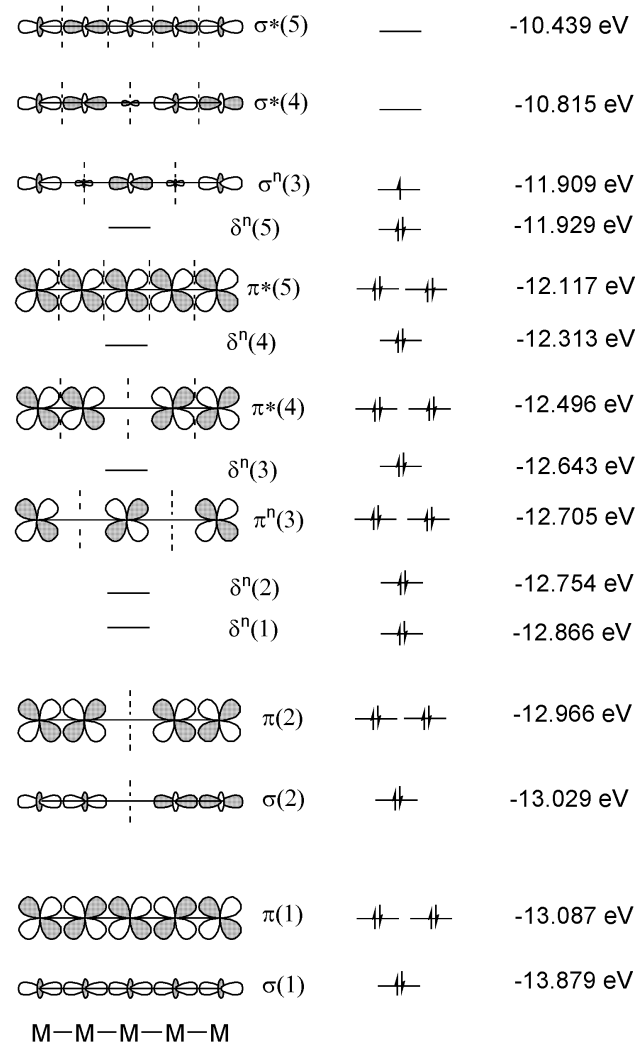

Fig. 1 Qualitative theoretical calculations for $\left[\mathrm{Co}_{5}(\mathrm{tpda})_{4}(\mathrm{NCS})_{2}\right]$. 


\begin{tabular}{llll}
\hline & IR $\left(v / \mathrm{cm}^{-1}\right)$ & UV/Vis/NIR $\left(\lambda_{\text {max }} / \mathrm{nm}\right)$ & MS $(m / z)$ \\
\hline $\mathbf{1}$ & $2060,1605,1575,1548,1473,1451$ & $289,339,391,513,722$ & 1455,1379 \\
$\mathbf{2}$ & $1601,1545,1470,1420$ & $294,331,351,524,752$ & $1409,1374,1339$ \\
$\mathbf{3}$ & $2038,1603,1575,1547,1473,1452,1409$ & $294,327,375,527,730$ & $1423,1381,1339$ \\
$\mathbf{4}$ & $2099,1605,1575,1547,1475,1452,1423,1410$ & $292,342,401,516,585,695$ & $1391,1365,1339$ \\
$\mathbf{5}$ & $1605,1579,1549,1475,1455,1413$ & $286,308,380,514,794$ & $1637,1488,1339$ \\
$\mathbf{6}$ & $2067,1603,1577,1548,1467,1424$ & $305,376,573,917$ & 1455,1397 \\
$\mathbf{7}$ & $1602,1577,1545,1467,1424$ & $306,374,585,939$ & $1409,1374,1339$ \\
$\mathbf{8}$ & $1603,1574,1548,1469,1423$ & $302,373,547,958$ & $1637,1488,1339$ \\
\hline
\end{tabular}

axial ligand influences the metal-metal interactions in the pentacobalt compounds. Therefore, a series of $\mathrm{Co}_{5}(\mathrm{tpda})_{4} \mathrm{X}_{2}$ complexes, where $\mathrm{X}$ is the axial ligand, were prepared and their crystal structures and physical properties were investigated.

The one and two-step spin-crossover phenomena have been found in the neutral and one-electron oxidation products, respectively, of linear tricobalt complexes.,10 The spincrossover phenomena observed in tricobalt complexes prompted us to investigate whether the neutral and oneelectron oxidized analogues of the pentanuclear cobalt complexes can undergo the spin-crossover process. In addition to the neutral compounds, a series of one-electron oxidized complexes were also synthesized and structurally characterized, and their NMR and magnetic properties were investigated. A comparison was made between the structures and physical properties of the neutral and oxidized complexes. Based on the crystal structures, NMR data, and magnetic properties of the neutral and oxidized complexes, together with the MO calculations, the electronic configuration of the pentacobalt complexes is described.

For clarity, the pentacobalt complexes presented in this paper are as follows: $\left[\mathrm{Co}_{5}(\mathrm{tpda})_{4}(\mathrm{NCS})_{2}\right](\mathbf{1}),\left[\mathrm{Co}_{5}(\mathrm{tpda})_{4} \mathrm{Cl}_{2}\right]$ (2), $\left[\mathrm{Co}_{5}(\mathrm{tpda})_{4}\left(\mathrm{~N}_{3}\right)_{2}\right] \quad(3), \quad\left[\mathrm{Co}_{5}(\mathrm{tpda})_{4}(\mathrm{CN})_{2}\right] \quad(\mathbf{4}), \quad\left[\mathrm{Co}_{5}(\mathrm{tpda})_{4}-\right.$ $\left.\left(\mathrm{SO}_{3} \mathrm{CF}_{3}\right)_{2}\right](5), \quad\left[\mathrm{Co}_{5}(\mathrm{tpda})_{4}(\mathrm{NCS})_{2}\right]\left(\mathrm{ClO}_{4}\right) \quad(6), \quad\left[\mathrm{Co}_{5}(\mathrm{tpda})_{4}-\right.$ $\left.\mathrm{Cl}_{2}\right]\left(\mathrm{ClO}_{4}\right)(7),\left[\mathrm{Co}_{5}(\mathrm{tpda})_{4}\left(\mathrm{SO}_{3} \mathrm{CF}_{3}\right)_{2}\right]\left(\mathrm{SO}_{3} \mathrm{CF}_{3}\right)(\mathbf{8})$.

\section{Results and discussion}

\section{Synthesis}

We have developed a general method for the synthesis of a series of oligo- $\alpha$-pyridylamino ligands. The desired ligand, tpdaH $\mathrm{H}_{2}$, can be prepared from the reaction of 2,6-diaminopyridine with 2.5 equivalents of 2-chloropyridine in the presence of potassium $t$-butoxide. The reaction of $\operatorname{tpdaH}_{2}$ with $\mathrm{CoCl}_{2}$ in molten naphthalene generated the mononuclear complex in situ. The addition of potassium $t$-butoxide in $n$-butanol gave the expected product, $\left[\mathrm{Co}_{5}(\mathrm{tpda})_{4} \mathrm{Cl}_{2}\right]$, in $10 \%$ yield. Under modified conditions, a high yield $(42 \%)$ for the synthesis of $\left[\mathrm{Co}_{5}(\mathrm{tpda})_{4}(\mathrm{NCS})_{2}\right]$ was achieved, in which excess $\mathrm{NaSCN}$ was added immediately after the addition of potassium $t$-butoxide. The high yielding and reproducible reaction conditions allow us to obtain a large amount of material for ligand exchange and to prepare the oxidized counterparts. The one-electron oxidation products were obtained either by reacting the neutral complexes with silver salts or by bulk electrolysis at $E_{\text {appl. }}=+0.55 \mathrm{~V}$, a value which is more positive than the formal potential for the first oxidation. The synthesis of the ligand and the pentanuclear cobalt complexes, including both neutral and one-electron oxidation products, is outlined in Scheme 1. The spectroscopic data for compounds 1-8 are given in Table 1 .

Summaries of the structural data for compounds 1-5 and 6-8 are given in Tables 2 and 3, respectively. Table 4 gives some selected bond distances for compounds $\mathbf{1}-\mathbf{8}$. In all these complexes, the pentacobalt chain is helically wrapped by four tpda ligands, and is linear and symmetrical. In compounds $\mathbf{2}$ and $\mathbf{5}$, the molecule resides on a crystallographic site of 2-fold symmetry, with the central cobalt atom on a 2 -fold axis perpendic-

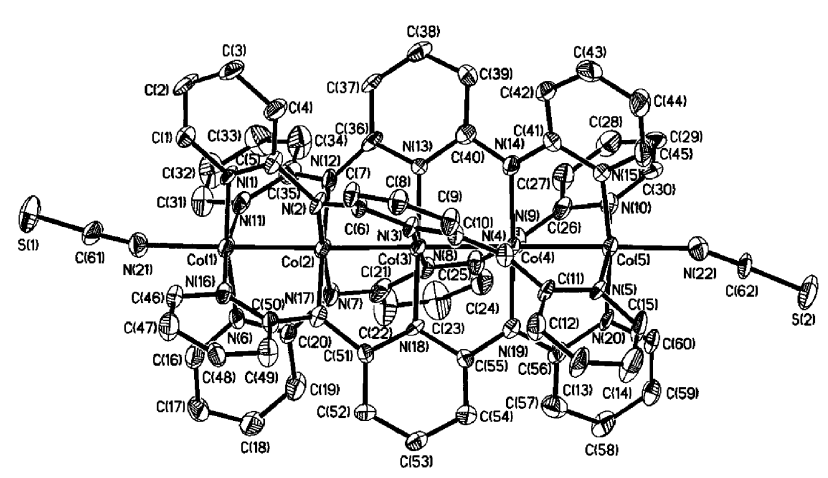

Fig. 2 Crystal structure of $\mathbf{1}$. Thermal ellipsoids are drawn at the 50\% probability level. Hydrogen atoms are omitted for clarity.

ular to the $\mathrm{Co}_{5}$ chain. The crystal structures of the neutral compounds 1-5 have a great deal in common, with only the axial ligands being different. As an example, Fig. 2 shows the crystal structure of compound 1. In the complexes, two types of $\mathrm{Co}-\mathrm{Co}$ bond distances are observed. The average internal Co-Co bond lengths fall into the range 2.22-2.24 $\AA$, whereas the external bonds range from 2.27 to $2.29 \AA$ A All of the $\mathrm{Co}-\mathrm{N}$ distances lie in the range 1.90-1.99 $\AA$. Unlike $\left[\mathrm{Co}_{3}(\mathrm{dpa})_{4} \mathrm{Cl}_{2}\right],{ }^{10}$ in which both symmetrical and asymmetrical forms can exist, the structure of $\left[\mathrm{Co}_{5}(\mathrm{tpda})_{4} \mathrm{X}_{2}\right]$ can only be observed in the symmetrical form.

It is possible that the identity of the axial ligand could influence the $\mathrm{Co}-\mathrm{Co}$ and $\mathrm{Co}-\mathrm{N}$ bond distances. Indeed, the weak nature of the axial ligand $\mathrm{SO}_{3} \mathrm{CF}_{3}{ }^{-}$in compound 5 is reflected in both the external $\mathrm{Co}-\mathrm{Co}$ and $\mathrm{Co}-\mathrm{N}$ bond distances, which are 0.026 and $0.025 \AA$ shorter, respectively, as compared to those of complex 4 , which has strong axial ligands $\left(\mathrm{CN}^{-}\right)$.

The molecular structures of the one-electron oxidized compounds 6-8 are similar to those of the neutral analogues, except for the presence of a counter anion to compensate for the positive charge on the $\mathrm{Co}_{5}$ core. Some selected bond distances are listed in Table 4. We expected that some of the interatomic bond distances would be shorter as compared to those in the neutral compounds. However, the $\mathrm{Co}-\mathrm{N}$ distances for all the cobalt atoms remain essentially unchanged upon one-electron oxidation. Moreover, all of the $\mathrm{Co}-\mathrm{Co}$ bond lengths are slightly longer (by about 0.01-0.02 $\AA$ ) than those in the neutral analogues. Fig. 3 shows the crystal structure of compound $\mathbf{6}$.

In the case of tricobalt complexes, the average $\mathrm{Co}-\mathrm{Cl}$ bond distance in the one-electron oxidized species is $0.15 \AA$ shorter than that for the neutral analogue. ${ }^{10}$ This is a result of the removal of one electron from the singly occupied HOMO, which has $\mathrm{Co}-\mathrm{Co}$ nonbonding and $\mathrm{Co}-\mathrm{Cl}$ antibonding character, as suggested by theoretical calculations. ${ }^{18}$ Similar to the case of the tricobalt compounds, theoretical calculations for the pentacobalt complexes reveal that the singly occupied HOMO also has metal-metal nonbonding and metal-axial ligand antibonding character. It was expected that removal of an electron from the HOMO of the neutral complexes would result in a decrease in the $\mathrm{Co}-\mathrm{Cl}$ bond distances and the $\mathrm{Co}-\mathrm{Co}$ distances would remain unchanged. However, a significant decrease in the 


\begin{tabular}{|c|c|c|c|c|c|}
\hline & $\begin{array}{l}\mathbf{1} \cdot \mathrm{CH}_{2} \mathrm{Cl}_{2} \cdot 1 / 2 \mathrm{Et}_{2} \mathrm{O} \cdot \\
1 / 2 \mathrm{H}_{2} \mathrm{O}\end{array}$ & $\mathbf{2} \cdot 2 \mathrm{CHCl}_{3} \cdot \mathrm{Et}_{2} \mathrm{O}$ & $3 \cdot 2 \mathrm{CH}_{2} \mathrm{Cl}_{2} \cdot 1 / 3 \mathrm{H}_{2} \mathrm{O}$ & $4 \cdot 3 \mathrm{CH}_{2} \mathrm{Cl}_{2} \cdot \mathrm{Et}_{2} \mathrm{O}$ & $5 \cdot 2 \mathrm{CH}_{2} \mathrm{Cl}_{2}$ \\
\hline Formula & $\mathrm{C}_{65} \mathrm{H}_{52} \mathrm{Cl}_{2} \mathrm{Co}_{5} \mathrm{~N}_{22} \mathrm{~S}_{2} \mathrm{O}$ & $\mathrm{C}_{66} \mathrm{H}_{56} \mathrm{Cl}_{8} \mathrm{Co}_{5} \mathrm{~N}_{20} \mathrm{O}$ & $\mathrm{C}_{62} \mathrm{H}_{48.67} \mathrm{Cl}_{4} \mathrm{Co}_{5} \mathrm{~N}_{26} \mathrm{O}_{0.33}$ & $\mathrm{C}_{69} \mathrm{H}_{60} \mathrm{Cl}_{6} \mathrm{Co}_{5} \mathrm{~N}_{22} \mathrm{O}$ & $\mathrm{C}_{64} \mathrm{H}_{48} \mathrm{Cl}_{4} \mathrm{Co}_{5} \mathrm{~F}_{6} \mathrm{~N}_{20} \mathrm{O}_{6} \mathrm{~S}_{2}$ \\
\hline Formula weight & 1586.96 & 1723.56 & 1599.72 & 1720.74 & 1807.79 \\
\hline Temperature/K & $295(2)$ & $150(1)$ & $150(1)$ & $150(1)$ & $150(1)$ \\
\hline Crystal system & Triclinic & Monoclinic & Rhombohedral & Monoclinic & Monoclinic \\
\hline Space group & $P \overline{1}$ & $C 2 / c$ & $R \overline{3}$ & $P 2_{1} / c$ & $C 2 / c$ \\
\hline$a / \AA ̊$ & $11.802(2)$ & $27.5435(5)$ & $40.3422(11)$ & $21.1260(1)$ & $24.2255(4)$ \\
\hline b/Å & $14.631(3)$ & $13.7477(3)$ & $40.3422(11)$ & $16.0070(1)$ & $15.2801(3)$ \\
\hline$c / \AA ̊$ & $20.184(4)$ & $18.6694(4)$ & $21.0202(6)$ & $22.6729(2)$ & $19.3286(3)$ \\
\hline$a /^{\circ}$ & $73.42(2)$ & 90 & 90 & 90 & 90 \\
\hline$\beta 1^{\circ}$ & $77.77(2)$ & $99.4304(8)$ & 90 & $111.6851(4)$ & $103.1489(7)$ \\
\hline$\gamma /{ }^{\circ}$ & $87.56(2)$ & 90 & 120 & 90 & 90 \\
\hline$V / \AA^{3}, Z$ & $3263.9(11), 2$ & $6973.8(2), 4$ & $29626.9(14), 18$ & $7124.54(8), 4$ & $6967.2(2), 4$ \\
\hline $\begin{array}{l}\text { Absorption } \\
\text { coefficient } / \mathrm{mm}^{-1}\end{array}$ & 1.453 & 1.531 & 1.460 & 1.427 & 1.463 \\
\hline Crystal size/mm & $0.50 \times 0.05 \times 0.05$ & $0.50 \times 0.40 \times 0.15$ & $0.48 \times 0.12 \times 0.10$ & $0.40 \times 0.35 \times 0.25$ & $0.25 \times 0.20 \times 0.10$ \\
\hline $\begin{array}{l}\theta \text { Range for } \\
\text { data collection }{ }^{\circ}\end{array}$ & $1.54-22.50$ & $1.93-27.50$ & $1.01-27.50$ & $1.70-27.50$ & $1.73-27.50$ \\
\hline Reflections collected & 8526 & 38777 & 89076 & 106884 & 24766 \\
\hline $\begin{array}{l}\text { Independent reflections } \\
\left(R_{\text {int }}\right)\end{array}$ & $8526(0.0000)$ & $7956(0.0719)$ & $15139(0.0498)$ & $16333(0.0620)$ & $8002(0.0556)$ \\
\hline$R_{F}, R_{w F^{2}}(\text { all data })^{a}$ & $0.1451,0.1290$ & $0.1220,0.2671$ & $0.0792,0.1861$ & $0.0882,0.1754$ & $0.1080,0.2041$ \\
\hline$R_{F}, R_{w F^{2}}[I>2 \sigma(I)]^{a}$ & $0.0491,0.1067$ & $0.0807,0.2309$ & $0.0537,0.1644$ & $0.0570,0.1480$ & $0.0635,0.1697$ \\
\hline GOF & 1.001 & 1.030 & 1.054 & 1.046 & 1.051 \\
\hline
\end{tabular}

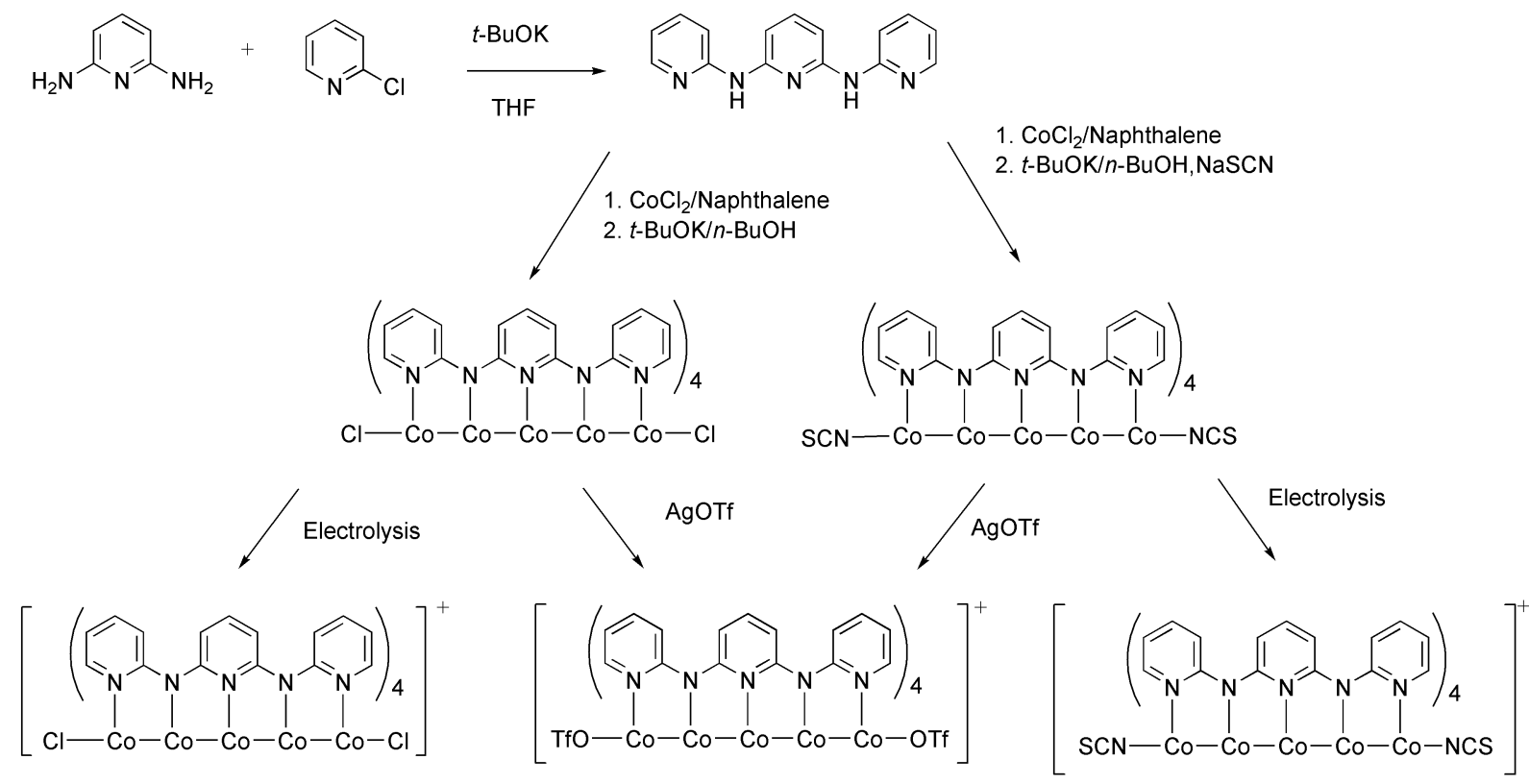

Scheme 1 General route for the preparation of the pentadentate ligand $N, N^{\prime}$-dipyridyl-2,6-diaminopyridine $\left.(\operatorname{tpdaH})_{2}\right)$ and linear pentanuclear cobalt string complexes.

Co-X bond distances was not observed upon one-electron oxidation. We believe that the electron cannot be removed from the singly occupied HOMO $\sigma^{\mathrm{n}}(3)$ orbital, but comes instead from the $\delta^{\mathrm{n}}(5)$ orbital to form a paramagnetic complex with $S=1$, as will be discussed later on.

\section{Magnetic properties}

It has been shown that the trinuclear cobalt complex $\left[\mathrm{Co}_{3}-\right.$ (dpa) ${ }_{4} \mathrm{Cl}_{2}$ ] undergoes a spin-crossover process at temperatures above $160 \mathrm{~K} .{ }^{7,10}$ Unlike $\left[\mathrm{Co}_{3}(\mathrm{dpa})_{4} \mathrm{Cl}_{2}\right]$, the phenomenon of spin crossover is not observed for the neutral pentacobalt complexes at temperatures below $300 \mathrm{~K}$. As previously reported, the effective moment of $1.90 \mu_{\mathrm{B}}$ at $300 \mathrm{~K}$ for $\left[\mathrm{Co}_{5}(\mathrm{tpda})_{4}(\mathrm{NCS})_{2}\right]$ is consistent with the MO calculations, the results of which are shown in Fig. 1. ${ }^{12}$ Based on the theoretical calculations, the oneelectron oxidation products of the pentacobalt complexes should be diamagnetic if the electron is removed from the singly occu- pied HOMO of the neutral analogues. However, an effective magnetic moment of $0.0 \mu_{\mathrm{B}}$ was not observed for the one-electron oxidized complexes at temperatures from 5 to $300 \mathrm{~K}$. The molar magnetic susceptibility $\left(\chi^{\mathrm{M}}\right)$ and effective magnetic moment $\left(\mu_{\text {eff }}\right)$ of compounds 6 versus temperature are presented in Fig. 4. The measured $\mu_{\text {eff }}$ values are essentially constant between 50 and $300 \mathrm{~K}$, and closely follow the Curie law. The effective magnetic moment of $2.93 \mu_{\mathrm{B}}$ at $300 \mathrm{~K}$ indicates that the complex is paramagnetic and that there are two unpaired electrons in the molecule, even though the measured value is slightly higher than expected $\left(\mathrm{ca} .2 .83 \mu_{\mathrm{B}}\right)$. At temperatures below $50 \mathrm{~K}$, the effective magnetic moment drops sharply as the temperature decreases. This indicates that there are antiferromagnetic interactions or spin-pairing in the $\mathrm{Co}_{5}$ unit. Similar magnetic behavior for one-electron oxidized complexes $\mathbf{7}$ and $\mathbf{8}$, with effective moments of 3.18 and $2.86 \mu_{\mathrm{B}}$, respectively, at $300 \mathrm{~K}$ is also observed. On the basis of the magnetic measurements, the 


\begin{tabular}{llll}
\hline & $\mathbf{6}$ & $\mathbf{7 \cdot 3} \mathrm{CH}_{2} \mathrm{Cl}_{2}$ & $\mathbf{8}$ \\
\hline Formula & & & \\
Formula weight & $\mathrm{C}_{62} \mathrm{H}_{44} \mathrm{ClCo}_{5} \mathrm{~N}_{22} \mathrm{~S}_{2} \mathrm{O}_{4}$ & $\mathrm{C}_{63} \mathrm{H}_{50} \mathrm{Cl}_{9} \mathrm{Co}_{5} \mathrm{~N}_{20} \mathrm{O}_{4}$ & $\mathrm{C}_{63} \mathrm{H}_{44} \mathrm{Co}_{5} \mathrm{~F}_{9} \mathrm{~N}_{22} \mathrm{O}_{9} \mathrm{~S}_{3}$ \\
Temperature/K & 1555.41 & 1764.93 & 1787.01 \\
Crystal system & $150(1)$ & $150(1)$ & $150(1)$ \\
Space group & Orthorhombic & Monoclinic & Monoclinic \\
$a / \AA$ & $P b c a$ & $P n$ & $P 2_{1}$ \\
$b / \AA$ & $17.6284(3)$ & $15.6128(2)$ & $13.8809(2)$ \\
$c / \AA$ & $17.1624(7)$ & $27.9023(5)$ & $17.2756(2)$ \\
$\beta /{ }^{\circ}$ & $40.0873(4)$ & $15.8641(3)$ & $13.9058(2)$ \\
$V / \AA^{3}, Z$ & 90 & $92.3899(14)$ & $99.7585(4)$ \\
Absorption coefficient $/ \mathrm{mm}^{-1}$ & $12128.2(4), 8$ & $6904.9(2), 4$ & $3286.37(8), 2$ \\
Crystal size/mm & 1.523 & 1.589 & 1.433 \\
$\theta$ Range for data collection/ & $0.30 \times 0.30 \times 0.10$ & $0.40 \times 0.27 \times 0.02$ & $0.20 \times 0.12 \times 0.04$ \\
Reflections collected & $1.54-25.00$ & $1.46-27.50$ & $2.36-27.50$ \\
Independent reflections $\left(R_{\text {int }}\right)$ & 27753 & 44517 & 48312 \\
$R_{F}, R_{w} F^{2}(\text { all data })^{a}$ & $9118(0.0647)$ & $26581(0.0592)$ & $13837(0.0544)$ \\
$R_{F}, R_{w} F^{2}[I>2 \sigma(I)]^{a}$ & $0.0895,0.1684$ & $0.1170,0.2241$ & $0.0700,0.1337$ \\
$\mathrm{GOF}$ & $0.0581,0.1444$ & $0.0786,0.1921$ & $0.0538,0.1476$ \\
${ }^{a} R_{F}=\Sigma\left|F_{\mathrm{o}}-F_{\mathrm{c}}\right| / \Sigma\left|F_{\mathrm{o}}\right| ; R_{w} F^{2}=\left[\Sigma w\left|F_{\mathrm{o}}{ }^{2}-F_{\mathrm{c}}{ }^{2}\right|^{2} / \Sigma w F_{\mathrm{o}}\right]^{4 / 2}$. & 1.122 & 1.046 \\
\hline
\end{tabular}

Table 4 Selected bond distances for compounds 1-8

\begin{tabular}{|c|c|c|c|c|c|c|c|c|}
\hline & 1 & 2 & 3 & 4 & 5 & 6 & 7 & 8 \\
\hline $\operatorname{Co}(1)-\mathrm{X}^{a}$ & $2.076(7)$ & $2.445(2)$ & $2.093(4)$ & $2.024(2)$ & $2.244(3)$ & $2.076(5)$ & $2.416(3)$ & $2.186(4)$ \\
\hline $\operatorname{Co}(5)-X^{a}$ & $2.071(8)$ & $2.445(2)$ & $2.089(4)$ & $2.038(4)$ & $2.244(3)$ & $2.037(6)$ & $2.408(3)$ & $2.213(4)$ \\
\hline $\mathrm{Co}(1)-\mathrm{Co}(2)$ & $2.276(2)$ & $2.282(1)$ & $2.258(1)$ & $2.279(1)$ & $2.253(1)$ & $2.292(1)$ & $2.300(2)$ & $2.282(1)$ \\
\hline $\mathrm{Co}(2)-\mathrm{Co}(3)$ & $2.232(2)$ & $2.235(1)$ & $2.223(1)$ & $2.227(1)$ & $2.225(1)$ & $2.238(1)$ & $2.246(2)$ & $2.253(1)$ \\
\hline $\mathrm{Co}(3)-\mathrm{Co}(4)$ & $2.232(2)$ & $2.235(1)$ & $2.221(1)$ & $2.231(1)$ & $2.225(1)$ & $2.243(1)$ & $2.244(2)$ & $2.241(1)$ \\
\hline $\operatorname{Co}(4)-\operatorname{Co}(5)$ & $2.271(2)$ & $2.282(1)$ & $2.264(1)$ & $2.286(1)$ & $2.253(1)$ & $2.276(1)$ & $2.285(2)$ & $2.290(1)$ \\
\hline $\mathrm{Co}(1)-\mathrm{N}$ & $1.975(7)$ & $1.983(5)$ & $1.972(4)$ & $1.982(3)$ & $1.960(4)$ & $1.973(5)$ & $1.989(8)$ & $1.967(6)$ \\
\hline $\mathrm{Co}(2)-\mathrm{N}$ & $1.899(7)$ & $1.914(4)$ & $1.906(4)$ & $1.909(3)$ & $1.914(4)$ & $1.902(4)$ & $1.901(8)$ & $1.884(5)$ \\
\hline $\mathrm{Co}(3)-\mathrm{N}$ & $1.930(7)$ & $1.930(4)$ & $1.934(3)$ & $1.932(3)$ & $1.938(4)$ & $1.932(4)$ & $1.926(7)$ & $1.920(5)$ \\
\hline $\mathrm{Co}(4)-\mathrm{N}$ & $1.903(7)$ & $1.914(4)$ & $1.922(3)$ & $1.914(3)$ & $1.914(4)$ & $1.900(5)$ & $1.901(8)$ & $1.895(5)$ \\
\hline $\mathrm{Co}(5)-\mathrm{N}$ & $1.970(8)$ & $1.983(5)$ & $1.970(4)$ & $1.987(3)$ & $1.960(4)$ & $1.969(5)$ & $1.987(8)$ & $1.961(5)$ \\
\hline
\end{tabular}

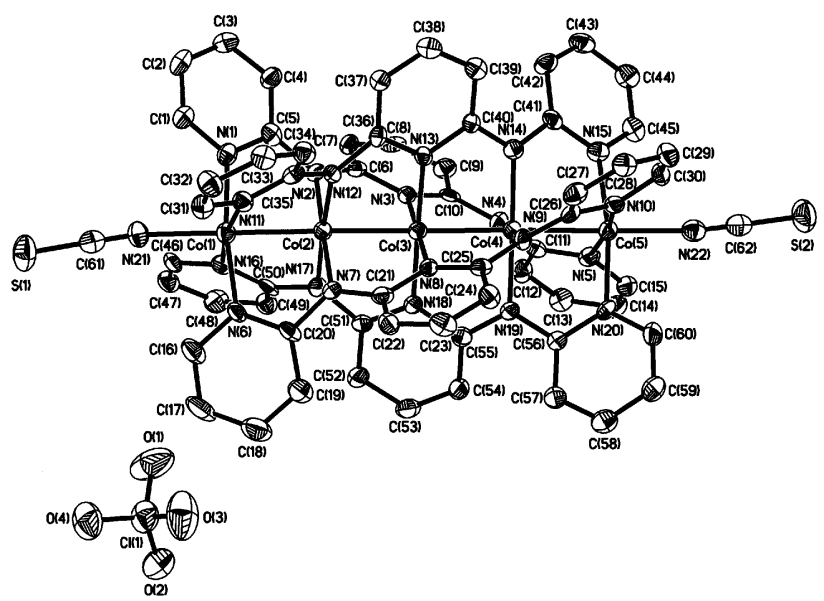

Fig. 3 Crystal structure of 6. Thermal ellipsoids are drawn at the 50\% probability level. Hydrogen atoms are omitted for clarity.

electronic configuration of the one-electron oxidation products of $\left[\mathrm{Co}_{5}(\mathrm{tpda})_{4} \mathrm{X}_{2}\right]$ can best be described as the molecules being in a high-spin $(S=1)$ state, where both the $\sigma^{\mathrm{n}}(3)$ and $\delta^{\mathrm{n}}(5)$ orbitals are singly occupied (Fig. 1). This provides an explanation as to why the metal-ligand bond distances do not change as significantly as those in the case of trinuclear cobalt complex $\left[\mathrm{Co}_{3}(\mathrm{dpa})_{4} \mathrm{Cl}_{2}\right]$ upon one-electron oxidation.

\section{NMR spectroscopy}

To ascertain whether both the neutral and one-electron oxidized pentacobalt complexes are paramagnetic, as revealed

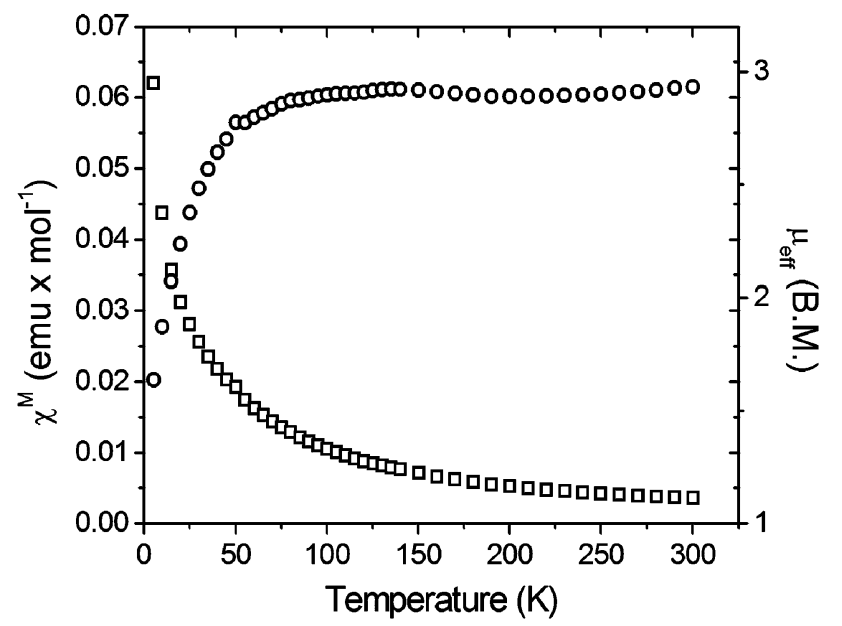

Fig. 4 Temperature-dependent magnetic effective moment $(\bigcirc)$ and molar magnetic susceptibility $(\square)$ for compound $\mathbf{6}$

by magnetic measurements, we decided to examine the ${ }^{1} \mathrm{H}$ NMR spectra. Fig. 5 shows the ${ }^{1} \mathrm{H}$ NMR spectra of complexes 1 and $\mathbf{6}$ at room temperature. As expected for paramagnetic complexes, broadened peaks and large chemical shifts for the resonance signals were observed for both compounds $\mathbf{1}$ and $\mathbf{6}$. For the symmetrical structures of $\mathbf{1}$ and $\mathbf{6}$, there should be only six peaks. Indeed, six lines with intensity ratios consistent with those expected (i.e., $2: 2: 2: 2: 2: 1$ ) centered at $21.19,8.51$, $4.47,-1.58,-2.51$, and $-6.01 \mathrm{ppm}$ were recorded for 1 . The spectrum of 6 also consists of six signals, spanning a larger range, appearing at $32.05,21.16,16.24,-15.33,-19.34$, and 


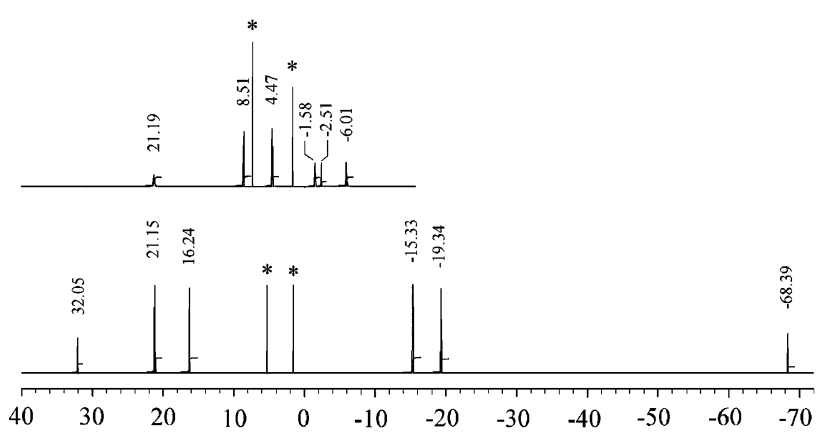

Fig. $5{ }^{1} \mathrm{H}$ NMR spectra of compounds 1 (top) and 6 (bottom) in $\mathrm{CDCl}_{3}$ and $\mathrm{CD}_{2} \mathrm{Cl}_{2}$, respectively, at $20^{\circ} \mathrm{C}$. The starred peaks arise from the solvent.

$-68.39 \mathrm{ppm}$, with the expected intensity ratios. Similar to compounds 1 and $\mathbf{6}$, the spectra of both compounds 2 and 7 consist of six signals in similar ranges to those of $\mathbf{1}$ and $\mathbf{6}$, respectively. The ${ }^{1} \mathrm{H}$ NMR spectra of these neutral and one-electron oxidized pentanuclear cobalt complexes clearly show the paramagnetism of these compounds in solution at room temperature, although we are unable to make a straightforward assignment for each of the resonance peaks simply by 1-D ${ }^{1} \mathrm{H}$ NMR. These data are consistent with the fact that the electron is not removed from the singly occupied HOMO $\sigma^{\mathrm{n}}(3)$ of the neutral molecules upon one-electron oxidation.

\section{Electrochemistry}

The electrochemistry of compounds $\mathbf{1} \mathbf{- 4}$ has been studied. Fig. 6 shows their cyclic voltammograms in $\mathrm{CH}_{2} \mathrm{Cl}_{2}$ containing

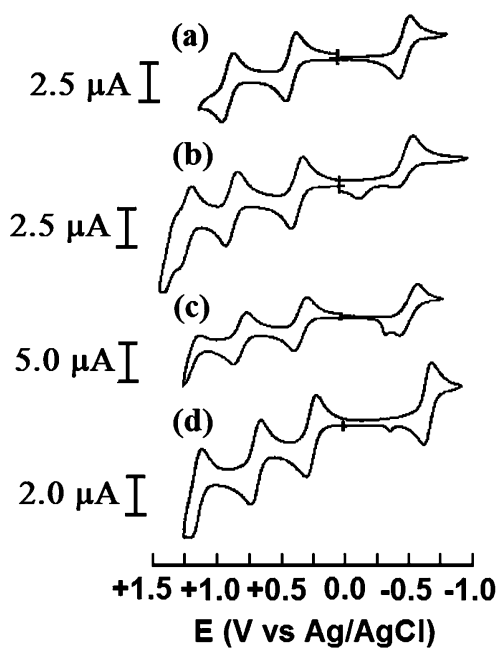

Fig. 6 The cyclic voltammograms of linear pentanuclear string complexes in $\mathrm{CH}_{2} \mathrm{Cl}_{2}$ containing $0.1 \mathrm{M}$ TBAP: (a) $\mathbf{1}$; (b) 2 ; (c) $\mathbf{3}$; (d) 4 .

0.1 M TBAP. All these complexes exhibit two reversible redox couples at about $E_{1 / 2}=+0.35$ and $+0.85 \mathrm{~V}$. Both electrochemical reactions involve one-electron transfer, as ascertained by spectroelectrochemistry. ${ }^{19}$ For compound 2 , another two oxidative waves at potentials of about +1.25 and $+1.40 \mathrm{~V}$, which are well resolved by using differential pulse techniques, are observed and each step involves one-electron abstraction, judging from the peak current maxima. The first reduction near $-0.50 \mathrm{~V}$ is reversible for $\mathbf{1}$, and irreversible for $\mathbf{2} \mathbf{- 4}$. For compound 4, a small reduction peak near $-0.35 \mathrm{~V}$ was observed upon the first reduction. This peak progressively increases as the potential is scanned in cycles between 0.00 and $-0.75 \mathrm{~V}$, indicating that an absorbed species forms when compound $\mathbf{4}$ is electrochemically reduced. The electrochemical reductive behavior of $\mathbf{4}$ and the characterization of the adsorbed species will be published elsewhere.

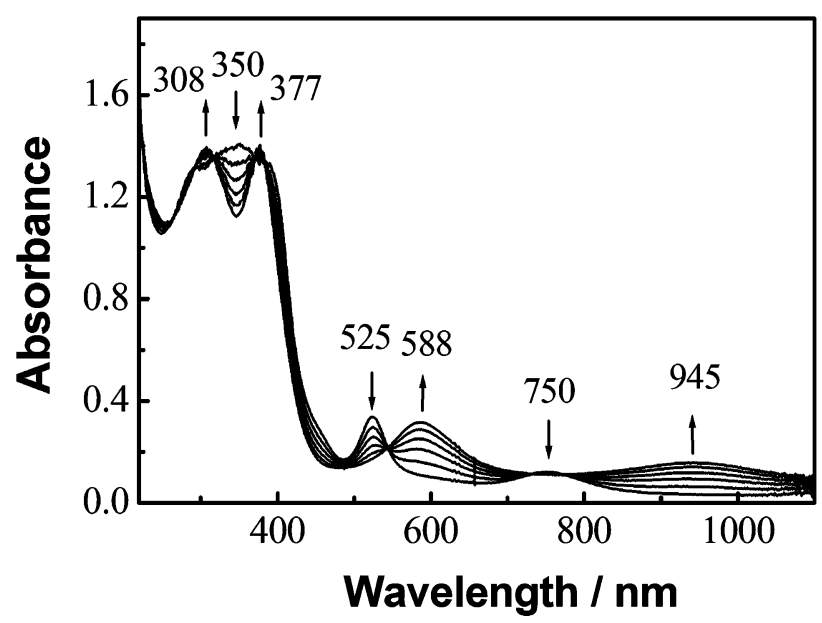

Fig. 7 UV/Vis spectral changes for the first oxidation of compound 1 in $\mathrm{CH}_{2} \mathrm{Cl}_{2}$ with $0.1 \mathrm{M}$ TBAP at various applied potentials from +0.18 to $+0.44 \mathrm{~V}$.

Fig. 7 shows the spectral changes observed for compound $\mathbf{2}$ at applied potentials from +0.18 to $+0.44 \mathrm{~V}$ in $\mathrm{CH}_{2} \mathrm{Cl}_{2}$ containing $0.1 \mathrm{M}$ TBAP. The peaks at 350,525 and $750 \mathrm{~nm}$ decrease in intensity, while those at 308, 377, 588 and $945 \mathrm{~nm}$ become stronger as the applied potential is increased, with clear isosbestic points at 293, 317, 370, 383, 543, 733 and $774 \mathrm{~nm}$. The resulting spectrum is similar to that of the one-electron oxidation product of $\mathbf{2}$, obtained by a chemical method, suggesting that the oxidation is a metal-centered reaction. Based on the spectral changes observed for $\mathbf{2}$ at various applied potentials, the number of electrons transferred is calculated to be one. ${ }^{19}$ The one-electron oxidation species of $\mathbf{2}$ is then characterized as $\left[\mathrm{Co}_{5}(\mathrm{tpda})_{4} \mathrm{Cl}_{2}\right]\left[\mathrm{ClO}_{4}\right]$, which is further confirmed by the X-ray crystal structure of complex 7.

The second oxidation was also investigated by spectroelectrochemistry, as shown in Fig. 8. The peaks at 308, 377, 588

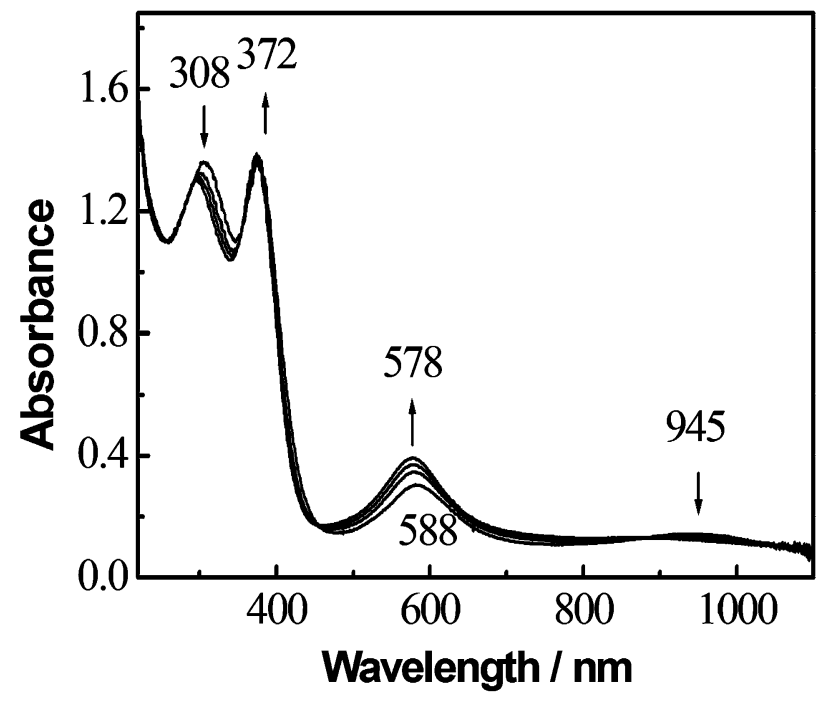

Fig. $8 \mathrm{UV} / \mathrm{Vis}$ spectral changes for the second oxidation of compound 1 in $\mathrm{CH}_{2} \mathrm{Cl}_{2}$ with $0.1 \mathrm{M}$ TBAP at various applied potentials from +0.60 to $+1.10 \mathrm{~V}$.

and $945 \mathrm{~nm}$ decrease in intensity, while those at 293, 372 and $578 \mathrm{~nm}$ become stronger as the applied potential is increased, with clear isosbestic points, suggesting that no intermediates are produced during the oxidation reactions. The oxidation reaction is reversible. The initial spectrum is restored completely upon re-reduction at $+0.55 \mathrm{~V}$. The number of electrons transferred in this oxidation reaction is one, which is calculated from the spectral changes at various applied potentials between 
+0.6 and $+1.10 \mathrm{~V}$. The result is consistent with that obtained by cyclic voltammetry. Attempts to isolate and crystallize the two-electron oxidation product were unsuccessful, although it was stable on the time scale of spectroelectrochemistry. The two-electron oxidized species undergoes reduction to form the corresponding one-electron oxidation product, as evidenced by the UV/Vis spectrum. The spectroelectrochemical behavior of complexes $\mathbf{1}, \mathbf{3}$ and $\mathbf{4}$ is similar to that of $\mathbf{2}$ However, the products of the second oxidation are relatively unstable.

\section{Conclusion}

This work describes the preparation, crystal structures, and properties of linear pentanuclear cobalt metal string complexes, including both neutral and one-electron oxidized compounds As far as we are aware, this is the first study on the one-electron oxidation products of the pentacobalt string complexes. Unlike the tricobalt system, all the structures of these complexes in this study are symmetrical and spin-crossover phenomena are not observed. The magnetic measurements show that the neutral and one-electron oxidized molecules exhibit spin states of $S=$ $1 / 2$ and 1 , respectively. These observations are consistent with the structural analyses, and rationalized by qualitative $\mathrm{MO}$ calculations. Our efforts are currently devoted to the synthesis of multicobalt complexes with longer chains and self-assembled multinuclear metal string complexes.

\section{Experimental}

\section{Materials}

All reagents and solvents were obtained from commercial sources and were used without further purification, unless otherwise noted. $\mathrm{CH}_{2} \mathrm{Cl}_{2}$ used for electrochemistry was dried over $\mathrm{CaH}_{2}$ and freshly distilled prior to use. $n-\mathrm{BuOH}$ was dried over magnesium turnings and freshly distilled prior to use Tetra- $n$-butylammonium perchlorate (TBAP) was recrystallized twice from ethyl acetate and dried under vacuum.

\section{Physical measurements}

Absorption spectra were recorded on a Hewlett Packard mode 8453 spectrophotometer. IR spectra were collected with a Nicolet Fourier-Transform IR spectrometer in the range 500$4000 \mathrm{~cm}^{-1}$. FAB mass spectra were obtained with a JEOL HX-110 HF double-focusing spectrometer operating in the positive ion detection mode. Molar magnetic susceptibility was recorded in the range $5-300 \mathrm{~K}$ on a SQUID system with a $10000 \mathrm{G}$ external magnetic field. Electrochemistry was performed with a three-electrode potentiostat (Bioanalytical Systems, Model CV-27) and a BAS X-Y recorder in $\mathrm{CH}_{2} \mathrm{Cl}_{2}$ solution deoxygenated by purging with purified nitrogen gas. Cyclic voltammetry was conducted using a home-made threeelectrode cell equipped with a BAS glassy carbon $\left(0.07 \mathrm{~cm}^{2}\right)$ or platinum $\left(0.02 \mathrm{~cm}^{2}\right)$ disk as the working electrode, a platinum wire as the auxiliary electrode, and a home-made $\mathrm{Ag} / \mathrm{AgCl}$ (sat'd) reference electrode. The reference electrode was separated from the bulk solution by a double junction filled with electrolyte solution. Potentials are reported vs. $\mathrm{Ag} / \mathrm{AgCl}$ (sat'd) and referenced to the ferrocene/ferrocenium $\left(\mathrm{Fc} / \mathrm{Fc}^{+}\right)$couple which occurs at $E_{1 / 2}=+0.54 \mathrm{~V} v s$. $\mathrm{Ag} / \mathrm{AgCl}$ (sat'd). The working electrode was polished with $0.03 \mu \mathrm{m}$ diameter aluminium oxide particles on Buehler felt pads and was cleaned ultrasonically for $1 \mathrm{~min}$ prior to each experiment. The reproducibility of individual potential values was within $\pm 5 \mathrm{mV}$. The spectroelectrochemical experiments were accomplished using a $1 \mathrm{~mm}$ cuvette, a 100 mesh platinum gauze as working electrode, a platinum wire as auxiliary electrode, and a $\mathrm{Ag} / \mathrm{AgCl}$ (sat'd) reference electrode.

\section{Preparation of compounds}

$\left[\mathrm{Co}_{5}\right.$ (tpda) $\left.{ }_{4}(\mathbf{N C S})_{2}\right]$ (1). tpdaH ${ }_{2}(1.05 \mathrm{~g}, 4.0 \mathrm{mmol}), \mathrm{CoCl}_{2}$ $(0.65 \mathrm{~g}, 5 \mathrm{mmol})$ and naphthalene $(20 \mathrm{~g})$ were placed in an Erlenmejer flask. After stirring the mixture at $160^{\circ} \mathrm{C}$ for $16 \mathrm{~h}$, $t$-BuOK $(0.9 \mathrm{~g}, 8.0 \mathrm{mmol})$ in $n$-butanol $(10 \mathrm{~mL})$ and NaSCN (3.24 g, $40 \mathrm{mmol})$ were added. The temperature was increased and $n$-butanol was slowly evaporated over a period of $30 \mathrm{~min}$. The resulting solution was then stirred at $220{ }^{\circ} \mathrm{C}$ for an additional $30 \mathrm{~min}$. After cooling the mixture to $80^{\circ} \mathrm{C}$, hexane $(100 \mathrm{~mL})$ was added and the resulting precipitate was filtered out. The solid was extracted with $\mathrm{CH}_{2} \mathrm{Cl}_{2}$ and recrystallized from $\mathrm{CH}_{2} \mathrm{Cl}_{2}$ and methanol to remove the mononuclear complex. Crystallization from $\mathrm{CH}_{2} \mathrm{Cl}_{2}$ and diethyl ether afforded dark brown crystals. Yield $0.61 \mathrm{~g}(42 \%)$. IR (KBr) $v / \mathrm{cm}^{-1}: 2060$ $(\mathrm{C} \equiv \mathrm{N}), 1605,1575,1548,1473,1451$ (py); UV/Vis $\left(\mathrm{CH}_{2} \mathrm{Cl}_{2}\right)$ $\lambda_{\max } / \mathrm{nm}\left(\varepsilon / \mathrm{dm}^{3} \mathrm{~mol}^{-1} \mathrm{~cm}^{-1}\right): 289\left(7.44 \times 10^{4}\right), 339\left(7.94 \times 10^{4}\right)$, $391\left(7.44 \times 10^{4}\right), 513\left(1.57 \times 10^{4}\right), 722\left(6.01 \times 10^{3}\right) ; \mathrm{MS}(\mathrm{FAB})$ $\mathrm{m} / \mathrm{z}: 1455\left(\left[\mathrm{Co}_{5}(\mathrm{tpda})_{4}(\mathrm{NCS})_{2}\right]^{+}\right), 1397\left(\left[\mathrm{Co}_{5}(\mathrm{tpda})_{4} \mathrm{NCS}\right]^{+}\right) ; \mathrm{EA}$ $(\%)\left[\mathrm{Co}_{5}(\mathrm{tpda})_{4}(\mathrm{NCS})_{2}\right]$ : calcd. C 51.15, H 3.05, N 21.17, found C 51.29, H 3.10, N 21.78 .

[Co $\mathbf{C o}_{5}$ (tpda) $\mathbf{C l}_{2}$ ] (2). tpdaH 2 (1.05 g, $\left.4.0 \mathrm{mmol}\right), \mathrm{CoCl}_{2}(0.65 \mathrm{~g}$, $5 \mathrm{mmol})$ and naphthalene $(20 \mathrm{~g})$ were placed in an Erlenmejer flask. After stirring the mixture at $160{ }^{\circ} \mathrm{C}$ for $16 \mathrm{~h}, t$-BuOK $(0.9 \mathrm{~g}, 8.0 \mathrm{mmol})$ in $n$-butanol $(10 \mathrm{~mL})$ was added. The temperature was increased and $n$-butanol was slowly evaporated over a period of $30 \mathrm{~min}$. The resulting solution was then stirred at $210^{\circ} \mathrm{C}$ for an additional $20 \mathrm{~min}$. After cooling the mixture to $80^{\circ} \mathrm{C}$, hexane $(100 \mathrm{~mL})$ was added and the precipitate was filtered out. The solid was extracted with $\mathrm{CH}_{2} \mathrm{Cl}_{2}$ and recrystallized from $\mathrm{CH}_{2} \mathrm{Cl}_{2}$ and methanol to remove the mononuclear complex. Crystallization from $\mathrm{CHCl}_{3}$ and diethyl ether gave dark brown crystals. Yield: $0.14 \mathrm{~g}(10 \%)$. IR $(\mathrm{KBr}) v / \mathrm{cm}^{-1}$ : $1601,1545,1470,1420$ (py); UV/Vis $\left(\mathrm{CH}_{2} \mathrm{Cl}_{2}\right) \lambda_{\max } / \mathrm{nm}\left(\varepsilon / \mathrm{dm}^{3}\right.$ $\left.\mathrm{mol}^{-1} \mathrm{~cm}^{-1}\right): 294\left(7.67 \times 10^{4}\right), 331\left(7.96 \times 10^{4}\right), 351\left(8.12 \times 10^{4}\right)$, $524\left(1.78 \times 10^{4}\right), 752\left(6.02 \times 10^{3}\right) ; \mathrm{MS}(\mathrm{FAB}) \mathrm{m} / \mathrm{z}: 1409\left(\left[\mathrm{Co}_{5^{-}}\right.\right.$ $\left.\left.(\text { tpda })_{4} \mathrm{Cl}_{2}\right]^{+}\right), 1374\left(\left[\mathrm{Co}_{5}(\mathrm{tpda})_{4} \mathrm{Cl}\right]^{+}\right), 1339\left(\left[\mathrm{Co}_{5}(\mathrm{tpda})_{4}\right]^{+}\right)$; EA

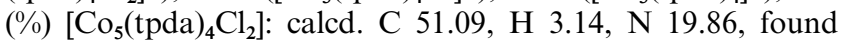
C $50.70, \mathrm{H} 3.27, \mathrm{~N} 19.88$.

$\left[\mathbf{C o}_{5}(\mathbf{t p d a})_{4}\left(\mathbf{N}_{3}\right)_{2}\right]$ (3). Method 1. tpdaH $(1.05 \mathrm{~g}, 4.0 \mathrm{mmol})$, $\mathrm{CoCl}_{2}(0.65 \mathrm{~g}, 5 \mathrm{mmol})$ and naphthalene $(20 \mathrm{~g})$ were placed in an Erlenmejer flask. After stirring the mixture at $160{ }^{\circ} \mathrm{C}$ for $16 \mathrm{~h}, t$-BuOK $(0.9 \mathrm{~g}, 8.0 \mathrm{mmol})$ in $n$-butanol $(10 \mathrm{~mL})$ was added. $\mathrm{NaN}_{3}(2.60 \mathrm{~g}, 40 \mathrm{mmol})$ was then added to the mixture portionwise. The temperature was increased and $n$-butanol was slowly evaporated over a period of $30 \mathrm{~min}$. The resulting solution was then stirred at $210{ }^{\circ} \mathrm{C}$ for an additional $10 \mathrm{~min}$. After cooling the mixture to $80^{\circ} \mathrm{C}$, hexane $(100 \mathrm{~mL})$ was added and the precipitate was filtered out. The solid was extracted with $\mathrm{CH}_{2} \mathrm{Cl}_{2}$ and recrystallized from $\mathrm{CH}_{2} \mathrm{Cl}_{2}$ and methanol to remove the mononuclear complex. Crystallization from $\mathrm{CH}_{2} \mathrm{Cl}_{2}$ and diethyl ether afforded dark brown crystals. Yield: $0.30 \mathrm{~g}$ (21\%). IR (KBr) $v / \mathrm{cm}^{-1}: 2038\left(\mathrm{~N}_{3}\right), 1603,1575,1547,1473$, 1452, 1409 (py); UV/Vis $\left(\mathrm{CH}_{2} \mathrm{Cl}_{2}\right) \lambda_{\max } / \mathrm{nm}\left(\varepsilon / \mathrm{dm}^{3} \mathrm{~mol}^{-1} \mathrm{~cm}^{-1}\right)$ : $294\left(5.85 \times 10^{4}\right), 327\left(6.10 \times 10^{4}\right), 375\left(6.00 \times 10^{4}\right), 527(1.64 \times$ $\left.10^{4}\right), 730\left(6.49 \times 10^{3}\right) ; \mathrm{MS}(\mathrm{FAB}) \mathrm{m} / \mathrm{z}: 1423\left(\left[\mathrm{Co}_{5}(\mathrm{tpda})_{4}\left(\mathrm{~N}_{3}\right)_{2}\right]^{+}\right)$, $1381\left(\left[\mathrm{Co}_{5}(\mathrm{tpda})_{4} \mathrm{~N}_{3}\right]^{+}\right), 1339\left(\left[\mathrm{Co}_{5}(\mathrm{tpda})_{4}\right]^{+}\right)$; EA $(\%)\left[\mathrm{Co}_{5}-\right.$ (tpda) $\left.)_{4}\left(\mathrm{~N}_{3}\right)_{2}\right] \cdot 2 \mathrm{CH}_{2} \mathrm{Cl}_{2}$ : calcd. C 46.73, H 3.04, N 22.85, found C 46.97, H 3.28, N 23.43 .

Method 2. To a solution of $\left[\mathrm{Co}_{5}(\mathrm{tpda})_{4}(\mathrm{NCS})_{2}\right](140 \mathrm{mg}$, $0.10 \mathrm{mmol})$ in $\mathrm{CH}_{2} \mathrm{Cl}_{2}(50 \mathrm{~mL})$ was added $\mathrm{AgClO}_{4}(70 \mathrm{mg}$, $0.33 \mathrm{mmol})$ in $\mathrm{CH}_{3} \mathrm{OH}(1 \mathrm{~mL})$. The solution turned from dark brown to bright blue. After stirring for $5 \mathrm{~min}$, the mixture was then filtered. $\mathrm{CH}_{3} \mathrm{OH}(50 \mathrm{~mL})$ and $\mathrm{NaN}_{3}(320 \mathrm{mg}, 50 \mathrm{mmol})$ were added to the filtrate. The resulting mixture was stirred overnight and then the solid was filtered out. The solvent was removed under reduced pressure. The product was obtained by crystallization via slow diffusion of diethyl ether vapor into a solution of the product in $\mathrm{CH}_{2} \mathrm{Cl}_{2}$. Yield: $102 \mathrm{mg}(72 \%)$. 
CAUTION: $\mathrm{NaN}_{3}$ is potentially explosive, although we did not experience any problems under the reaction conditions used.

$\left[\mathrm{Co}_{5}(\mathbf{t p d a})_{4}(\mathbf{C N})_{2}\right]$ (4). Method 1. To a solution of $\left[\mathrm{Co}_{5^{-}}\right.$ (tpda) $\left.{ }_{4} \mathrm{Cl}_{2}\right](140 \mathrm{mg}, 0.10 \mathrm{mmol})$ in a mixture of $\mathrm{CH}_{2} \mathrm{Cl}_{2}$ $(50 \mathrm{~mL})$ and $\mathrm{CH}_{3} \mathrm{OH}(50 \mathrm{~mL})$ was added $\mathrm{NaCN}(245 \mathrm{mg}$, $50 \mathrm{mmol}$ ). The resulting mixture was stirred overnight and then the solid was filtered out. The solvent was removed under reduced pressure. Crystals were obtained by crystallization via slow diffusion of diethyl ether vapor into the solution of the product in $\mathrm{CH}_{2} \mathrm{Cl}_{2}$. Yield: $120 \mathrm{mg}(86 \%)$. IR $(\mathrm{KBr}) v / \mathrm{cm}^{-1}: 2099$ $(\mathrm{C} \equiv \mathrm{N}), 1605,1575,1547,1475,1452,1423,1410$ (py); UV/Vis $\left(\mathrm{CH}_{2} \mathrm{Cl}_{2}\right) \lambda_{\max } / \mathrm{nm}\left(\varepsilon / \mathrm{dm}^{3} \mathrm{~mol}^{-1} \mathrm{~cm}^{-1}\right): 292\left(5.78 \times 10^{4}\right), 342$ $\left(6.55 \times 10^{4}\right), 401\left(4.64 \times 10^{4}\right), 516\left(9.98 \times 10^{3}\right), 585\left(5.49 \times 10^{3}\right)$ $695\left(6.49 \times 10^{3}\right) ; \mathrm{MS}(\mathrm{FAB}) \mathrm{m} / z: 1391\left(\left[\mathrm{Co}_{5}(\mathrm{tpda})_{4}(\mathrm{CN})_{2}\right]^{+}\right)$, $1365\left(\left[\mathrm{Co}_{5}(\mathrm{tpda})_{4} \mathrm{CN}\right]^{+}\right), 1339\left(\left[\mathrm{Co}_{5}(\mathrm{tpda})_{4}\right]^{+}\right)$; EA $(\%)\left[\mathrm{Co}_{5}\right.$ $(\text { tpda })_{4}(\mathrm{CN})_{2}$ ]: calcd. C 53.50, H 3.17, N 22.14, found C 53.17, H 3.33, N 22.09.

Method 2. A procedure similar to method 2 for 3 was employed, except that $\mathrm{NaCN}$ was used instead of $\mathrm{NaN}_{3}$, giving 4 in $73 \%$ yield.

$\left[\mathrm{Co}_{5}(\mathrm{tpda})_{4}\left(\mathrm{SO}_{3} \mathrm{CF}_{3}\right)_{2}\right](\mathbf{5})$. To a solution of $\left[\mathrm{Co}_{5}(\mathrm{tpda})_{4} \mathrm{Cl}_{2}\right]$ (140 mg, $0.10 \mathrm{mmol})$ in $\mathrm{CH}_{2} \mathrm{Cl}_{2}(50 \mathrm{~mL})$ was added $\mathrm{TlSO}_{3} \mathrm{CF}_{3}$ (177 mg, $0.50 \mathrm{mmol})$ in $\mathrm{CH}_{3} \mathrm{OH}(2 \mathrm{~mL})$. The resulting solution was stirred for $2 \mathrm{~h}$ and then filtered. the solvent was removed under reduced pressure. The product was obtained by crystallization via slow diffusion of diethyl ether vapor into a solution of the product in $\mathrm{CH}_{2} \mathrm{Cl}_{2}$. Yield: $150 \mathrm{mg}, 91 \%$. IR $(\mathrm{KBr}) v / \mathrm{cm}^{-1}$ : $1605,1579,1549,1475,1455,1413$ (py); UV/Vis $\left(\mathrm{CH}_{2} \mathrm{Cl}_{2}\right)$ $\lambda_{\text {max }} / \mathrm{nm}\left(\varepsilon / \mathrm{dm}^{3} \mathrm{~mol}^{-1} \mathrm{~cm}^{-1}\right): 286\left(5.23 \times 10^{4}\right), 308\left(5.36 \times 10^{4}\right)$, $380\left(5.67 \times 10^{4}\right), 514\left(8.98 \times 10^{3}\right), 794\left(2.64 \times 10^{3}\right) ; \mathrm{MS}(\mathrm{FAB})$ $\mathrm{m} / \mathrm{z}: 1637\left(\left[\mathrm{Co}_{5}(\mathrm{tpda})_{4}(\mathrm{OTf})_{2}\right]^{+}\right), 1488\left(\left[\mathrm{Co}_{5}(\mathrm{tpda})_{4} \mathrm{OTf}\right]^{+}\right), 1339$ $\left(\left[\mathrm{Co}_{5}(\mathrm{tpda})_{4}\right]^{+}\right)$; EA $(\%)\left[\mathrm{Co}_{5}(\mathrm{tpda})_{4}(\mathrm{OTf})_{2}\right]$ : calcd. C 45.47 , H 2.71, N 17.10, found C 45.28, H 2.84, N 17.40.

$\left[\mathrm{Co}_{5}(\text { tpda })_{4}(\mathrm{NCS})_{2}\right]\left(\mathrm{ClO}_{4}\right)$ (6). A solution of $\left[\mathrm{Co}_{5}(\mathrm{tpda})_{4^{-}}\right.$ $(\mathrm{NCS})_{2}$ ] $(100 \mathrm{mg})$ in $\mathrm{CH}_{2} \mathrm{Cl}_{2}(20 \mathrm{~mL})$ containing $0.1 \mathrm{M}$ TBAP was electrolyzed at $E_{\text {appl }}=+0.55 \mathrm{~V} v s$. $\mathrm{Ag} / \mathrm{AgCl}$. The reaction was monitored by UV/Vis spectroscopy. After the reaction was complete, the solution was concentrated under reduced pressure. Deep blue crystals were obtained by slow diffusion of diethyl ether vapor into a concentrated $\mathrm{CH}_{2} \mathrm{Cl}_{2}$ solution. Samples for analysis were recrystallized twice from $\mathrm{CH}_{2} \mathrm{Cl}_{2}$ and diethyl ether. Yield: $77 \mathrm{mg}(72 \%)$. IR ( KBr) $v / \mathrm{cm}^{-1}: 2067(\mathrm{C} \equiv \mathrm{N})$, $1603,1577,1548,1467,1424$ (py); UV/Vis $\left(\mathrm{CH}_{2} \mathrm{Cl}_{2}\right) \lambda_{\max } / \mathrm{nm}$ $\left(\varepsilon / \mathrm{dm}^{3} \mathrm{~mol}^{-1} \mathrm{~cm}^{-1}\right): 305\left(6.91 \times 10^{4}\right), 376\left(6.70 \times 10^{4}\right), 573(1.46$ $\left.\times 10^{4}\right), 917\left(6.95 \times 10^{3}\right) ; \mathrm{MS}(\mathrm{FAB}) \mathrm{m} / \mathrm{z}: 1455\left(\left[\mathrm{Co}_{5}(\mathrm{tpda})_{4^{-}}\right.\right.$ $\left.\left.(\mathrm{NCS})_{2}\right]^{+}\right), 1397 \quad\left(\left[\mathrm{Co}_{5}(\mathrm{tpda})_{4} \mathrm{NCS}\right]^{+}\right) ; \quad$ EA $(\%) \quad\left[\mathrm{Co}_{5}(\mathrm{tpda})_{4^{-}}\right.$ (NCS) $\left.)_{2}\right]\left(\mathrm{ClO}_{4}\right)$ : calcd. C 47.88, $\mathrm{H} \mathrm{2.85,} \mathrm{N} \mathrm{19.81,} \mathrm{found} \mathrm{C} \mathrm{47.88,}$ H 2.92, N 20.52.

$\left[\mathrm{Co}_{5}(\text { tpda })_{4} \mathrm{Cl}_{2}\right]\left(\mathrm{ClO}_{4}\right)(\mathbf{7})$. A procedure similar to that used to prepare 6 was employed, except that $\left[\mathrm{Co}_{5}(\mathrm{tpda})_{4} \mathrm{Cl}_{2}\right]$ instead of $\left[\mathrm{Co}_{5}(\mathrm{tpda})_{4}(\mathrm{NCS})_{2}\right]$ was used to obtain the product. Samples for analysis were crystallized twice from $\mathrm{CH}_{2} \mathrm{Cl}_{2}$ and diethyl ether Yield: $78 \mathrm{mg}(73 \%)$. IR (KBr) $v / \mathrm{cm}^{-1}: 1602,1577,1545,1467$, 1424 (py); UV/Vis $\left(\mathrm{CH}_{2} \mathrm{Cl}_{2}\right) \lambda_{\max } / \mathrm{nm}\left(\varepsilon / \mathrm{dm}^{3} \mathrm{~mol}^{-1} \mathrm{~cm}^{-1}\right): 306$ $\left(7.36 \times 10^{4}\right), 374\left(7.31 \times 10^{4}\right), 585\left(1.44 \times 10^{4}\right), 939\left(6.85 \times 10^{3}\right)$; MS(FAB) $m / z: 1409\left(\left[\mathrm{Co}_{5}(\text { tpda })_{4} \mathrm{Cl}_{2}\right]^{+}\right), 1374\left(\left[\mathrm{Co}_{5}(\text { tpda })_{4} \mathrm{Cl}\right]^{+}\right)$, $1339\left(\left[\mathrm{Co}_{5}(\mathrm{tpda})_{4} \mathrm{Cl}\right]^{+}\right)$; EA (\%) $\left[\mathrm{Co}_{5}(\mathrm{tpda})_{4} \mathrm{Cl}_{2}\right]\left(\mathrm{ClO}_{4}\right)$ : calcd. C 47.72, H 2.94, N 18.55, found C 47.46, H 3.05, N 19.06 .

[Co $\left.\mathrm{Co}_{5}(\mathrm{tpda})_{4}(\mathrm{OTf})_{2}\right](\mathrm{OTf})(8)$. To a solution of $\left[\mathrm{Co}_{5}(\mathrm{tpda})_{4^{-}}\right.$ $(\mathrm{NCS})_{2}$ ] $(145 \mathrm{mg}, 0.10 \mathrm{mmol})$ in $\mathrm{CH}_{2} \mathrm{Cl}_{2}(50 \mathrm{ml})$ was added AgOTf (103 mg, $0.40 \mathrm{mmol})$ in $\mathrm{CH}_{3} \mathrm{OH}(1 \mathrm{~mL})$. The resulting mixture was stirred for $5 \mathrm{~min}$. The solution turned from dark brown to bright blue. After filtering the solution, the solvent was removed under reduced pressure. The blue solid was dis- solved in a mixture of $\mathrm{CH}_{2} \mathrm{Cl}_{2}$ and $\mathrm{CH}_{3} \mathrm{OH}$, and crystallized by slow diffusion of diethyl ether vapor into the solution, giving dark blue crystals. Yield: $93 \mathrm{mg}(52 \%)$. IR $(\mathrm{KBr}) v / \mathrm{cm}^{-1}: 1603$, 1574, 1548, 1469, 1423 (py); UV/Vis $\left(\mathrm{CH}_{2} \mathrm{Cl}_{2}\right) \lambda_{\max } / \mathrm{nm}\left(\varepsilon / \mathrm{dm}^{3}\right.$ $\left.\mathrm{mol}^{-1} \mathrm{~cm}^{-1}\right): 302\left(1.26 \times 10^{5}\right), 373\left(1.29 \times 10^{5}\right), 574\left(2.11 \times 10^{4}\right)$, $958\left(8.58 \times 10^{3}\right) ; \mathrm{MS}(\mathrm{FAB}) \mathrm{m} / \mathrm{z}: 1637\left(\left[\mathrm{Co}_{5}(\text { tpda })_{4}(\mathrm{OTf})_{2}\right]^{+}\right)$, $1488\left(\left[\mathrm{Co}_{5}(\mathrm{tpda})_{4}(\mathrm{OTf})\right]^{+}\right), 1339 \quad\left(\left[\mathrm{Co}_{5}(\mathrm{tpda})_{4}\right]^{+}\right) ; \quad$ EA $(\%)$ $\left[\mathrm{Co}_{5}(\text { tpda })_{4}(\mathrm{OTf})_{2}\right](\mathrm{OTf})$ : calcd. C 42.34, H 2.48, N 15.68, found $\mathrm{C} 42.17, \mathrm{H} 2.57, \mathrm{~N} 16.00$.

\section{Crystal structure determination}

The selected crystals were mounted on a glass fiber. Data collection was carried out on a NONIUS CAD4 diffractometer for $\mathbf{1}$ and on a BRUKER SMART CCD for $\mathbf{3}$ with Mo-K $\alpha$ radiation $(\lambda=0.71073 \AA)$. Cell parameters were retrieved and refined using the CAD4 software ${ }^{20}$ on 25 reflections for $\mathbf{1}$, and using the SAINT software ${ }^{21}$ on all reflections for 3 . Data reduction was performed on the NRCSDP ${ }^{22}$ and SAINT ${ }^{21}$ software for $\mathbf{1}$ and 3, respectively. Empirical absorption corrections based on the symmetry-equivalent reflections and absorptions were applied with the PSI-SCAN and SADABS ${ }^{23}$ programs, respectively. Data collection for $\mathbf{2}$ and 4-8 was carried out on a NONIUS Kappa CCD diffractometer. Cell parameters were retrieved and refined using the DENZO-SMN software on all observed reflections. ${ }^{24}$ Data reduction was performed with the DENZO-SMN software. ${ }^{24}$ Empirical absorption corrections based on the symmetry-equivalent reflections and absorptions were applied with the SORTAV program. ${ }^{25}$ All the structures were solved using SHELXS-97 ${ }^{26}$ and refined with SHELXL$97^{27}$ by full-matrix least squares on $F^{2}$. Hydrogen atoms were fixed at calculated positions and refined using a riding mode. The detailed crystal data are listed in Tables 2 and 3.

CCDC reference numbers 176403-176410.

See http://www.rsc.org/suppdata/dt/b1/b111462j/ for crystallographic data in CIF or other electronic format.

\section{Acknowledgements}

The authors acknowledge the National Science Council and Ministry of Education of Taiwan for financial support.

\section{References}

1 F. A. Cotton and R. A. Walton, Multiple Bonds Between Metal Atoms, Clarendon Press, Oxford, 2nd edn., 1993.

2 F. A. Cotton and G. Wilkinson, Advanced Inorganic Chemistry, Wiley, New York, 5th edn., 1988, ch. 23.

3 G. Aullon, P. Alemany and S. Alvarez, Inorg. Chem., 1996, 35, 5061. 4 F. Mota, J. J. Novoa, J. Losada, S. Alvarez, R. Hoffmann and J. Silverstre, J. Am. Chem. Soc., 1993, 115, 6216; J. Losada, S. Alvarez, J. J. Novoa, F. Mota, R. Hoffmann and J. Silverstre, J. Am. Chem. Soc., 1990, 112, 8998.

5 S. Aduldecha and B. Hathaway, J. Chem. Soc., Dalton. Trans., 1991, 993

6 G. J. Pyrka, M. El-Mekki and A. A. Pinkerton, J. Chem. Soc., Chem. Commun., 1991, 84; L.-P. Wu, P. Field, T. Morrissey, C. Murphy, P. Nagle, B. Hathaway, C. Simmons and P. Thornton, J. Chem. Soc., Dalton. Trans., 1990, 3835.

7 E.-C. Yang, M.-C. Cheng, M.-S. Tsai and S.-M. Peng, J. Chem. Soc., Chem. Commun., 1994, 2377; J.-T. Sheu, C.-C. Lin, I. Chao, C.-C. Wang and S.-M. Peng, Chem. Commun., 1996, 315.

8 R. Clérac, F. A. Cotton, K. R. Dunbar, C. A. Murillo, I. Pascual and X. Wang, Inorg. Chem., 1999, 38, 2655; F. A. Cotton, L. M. Daniels, P. Lei, C. A. Murillo and X. Wang, Inorg. Chem., 2001, 40, 2778; R. Clérac, F. A. Cotton, L. M. Daniels, J. Gu, C. A. Murillo and H.-C. Zhou, Inorg. Chem., 2000, 39, 4488.

9 F. A. Cotton, L. M. Daniels, C. A. Murillo and I. Pascual, J. Am. Chem. Soc., 1997, 119, 10223; F. A. Cotton, L. M. Daniels, C. A. Murillo and I. Pascual, Inorg. Chem. Commun., 1998, 1, 1; R. Clérac, F. A. Cotton, L. M. Danniels, K. R. Dunbar, C. A. Murillo and I. Pascual, Inorg. Chem., 2000, 39, 748; R. Clérac, F. A. Cotton, L. M. Daniels, K. R. Dunbar, C. A. Murillo and I. Pascual, Inorg. Chem., 2000, 39, 752; R. Clérac, F. A. Cotton, 
L. M. Daniels, K. R. Dunbar, C. A. Murillo and H.-C. Zhou, Inorg. Chem., 2000, 39, 3414

10 F. A. Cotton, L. M. Daniels and G. T. Jordan IV, Chem. Commun., 1997, 421; F. A. Cotton, L. M. Daniels, G. T. Jordan IV and C. A. Murillo, J. Am. Chem. Soc., 1997, 119, 10377; F. A. Cotton, C. A. Murillo and X. Wang, Inorg. Chem., 1999, 38, 6294; F. A. Cotton, C. A. Murillo and X. Wang, J. Chem. Soc., Dalton Trans., 1999, 3327; R. Clérac, F. A. Cotton, L. M. Daniels, K. R. Dunbar, T. Lu, C. A. Murillo and X. Wang, J. Am. Chem Soc., 2000, 122, 2272; R. Clérac, F. A. Cotton, K. R. Dunbar, T. Lu, C. A. Murillo and X. Wang, Inorg. Chem., 2000, 39, 3065; R. Clérac, F. A. Cotton, L. M. Daniels, K. R. Dunbar, K. Kirschbaum, C. A. Murillo, A. A. Pinkerton, A. J. Schultz and X. Wang, J. Am. Chem. Soc., 2000, 122, 6226; R. Clérac, F. A. Cotton, L. M. Daniels, K. R. Dunbar, C. A. Murillo and X. Wang, J. Chem. Soc., Dalton Trans., 2001, 386; R. Clérac, F. A. Cotton, L. M. Daniels, K. R. Dunbar, C. A. Murillo and X. Wang, J. Am. Chem. Soc., 2001 123, 1256; R. Clérac, F. A. Cotton, S. P. Jeffery, C. A. Murillo and X. Wang, J. Am. Chem. Soc., 2001, 123, 1265.

11 S.-Y. Lai, T.-W. Lin, Y.-H. Chen, C.-C. Wang, G.-H. Lee, M.-H. Yang, M.-K. Leung and S.-M. Peng, J. Am. Chem. Soc., 1999, 121, 250; S.-Y. Lai, C.-C. Wang, Y.-H. Chen, C.-C. Lee, Y.-H. Liu and S.-M. Peng, J. Chin. Chem. Soc., 1999, 46, 477.

12 S.-J. Shieh, C.-C. Chou, G.-H. Lee, C.-C. Wang and S.-M. Peng, Angew. Chem., Int. Ed. Engl., 1997, 36, 56.

13 C.-C. Wang, W.-C. Lo, C.-C. Chou, G.-H. Lee, J.-M. Chen and S.-M. Peng, Inorg. Chem., 1998, 37, 4059.
14 H.-C. Chang, J.-T. Li, C.-C. Wang, T.-W. Lin, H.-C. Lee, G.-H. Lee and S.-M. Peng, Eur. J. Inorg. Chem., 1999, 1243.

15 F. A. Cotton, L. M. Daniels, C. A. Murillo and X. Wang, Chem. Commun., 1999, 2461; F. A. Cotton, L. M. Daniels, C. A. Murillo and X. Wang, J. Chem. Soc., Dalton Trans., 1999, 517.

16 Y.-H. Chen, C.-C. Lee, C.-C. Wang, G.-H. Lee, S.-Y. Lai, F.-Y. Li, C.-Y. Mou and S.-M. Peng, Chem. Commun., 1999, 1667.

17 S.-M. Peng, C.-C. Wang, Y.-L. Jang, Y.-H. Chen, F.-Y. Li, C.-Y. Mou and M.-K. Leung, J. Magn. Magn. Mater., 2000, 209, 80.

18 M.-M. Rohmer and M. Benard, J. Am. Chem. Soc., 1998, 120, 9372.

19 D. F. Rohrbach, E. Deutsch, W. R. Heineman and R. F. Pasternack, Inorg. Chem., 1977, 16, 2650.

20 CAD4 v. 5.0, Enraf-Nonius, Deft, The Netherlands, 1989.

21 SAINT v.6.02, Software for CCD Detector Integration, Bruker Analytical Instruments Division, Madison, WI, USA, 1997.

22 E. J. Gabe, Y. Lepage, J. P. Charpand, F. L. Lee and P. S. White, J. Appl. Crystallogr., 1989, 22, 384.

23 G. M. Sheldrick, SADABS, Program for Bruker Area Detector Absorption Correction, University of Göttingen, Germany, 1997.

24 Z. Otwinowski and W. Minor, in Methods in Enzymology, ed. C. W. Carter, Jr. and R. M. Sweet, Academic Press, London, 1997, vol. 276, pp. 307-326.

25 R. H. Blessing, Acta. Crystallogr., Sect. A, 1995, 51, 33.

26 G. M. Sheldrick, Acta. Crystallogr., Sect. A, 1990, 46, 467.

27 G. M. Sheldrick, SHELXL-97, Program for the Refinement of Crystal Structures, University of Göttingen, Germany, 1997. 